\title{
Perencanaan Jaringan Irigasi Hidroponik Guna Ekstensifikasi Lahan pada Sawah Tadah Hujan di Kelurahan Made, Kecamatan Sambikerep, Kota Surabaya
}

\author{
Choirul Anwar ${ }^{1}$, S. Kamilia Aziz ${ }^{1}$, Dwi Indriyani ${ }^{1, *}$, Deris Faisa Ralindra ${ }^{1}$, Fitria Wahyuni ${ }^{1}$ \\ Departemen Teknik Infrastruktur Sipil, Institut Teknologi Sepuluh Nopember, Surabaya ${ }^{1}$ \\ Koresponden*,Email: d.indriyani@ce.its.ac.id
}

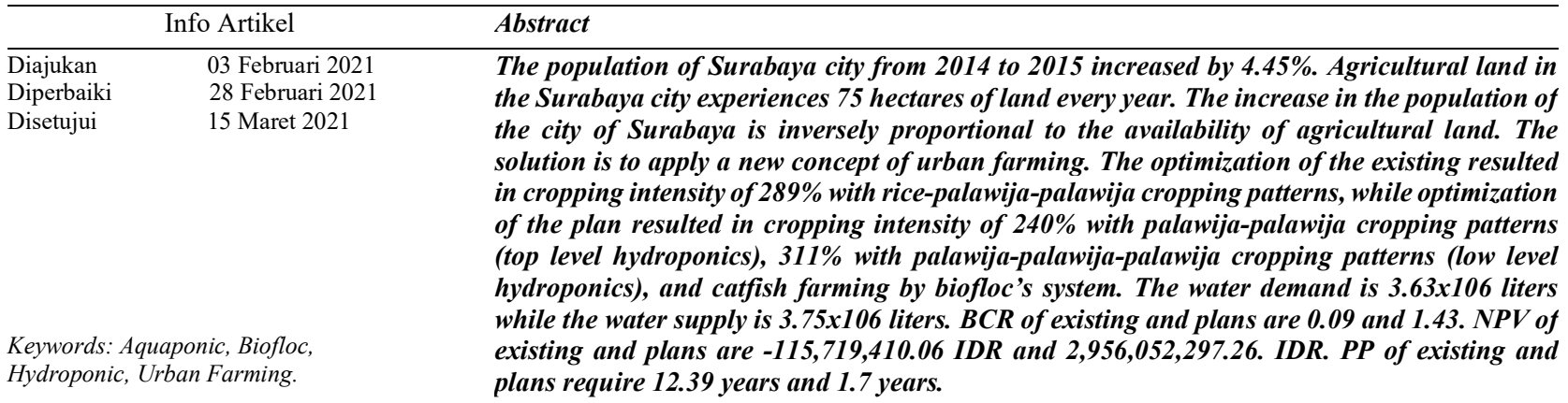

\begin{abstract}
Abstrak
Jumlah penduduk Kota Surabaya dari tahun 2014 sampai 2015 mengalami peningkatan sebesar 4,45\%. Lahan pertanian di Kota Surabaya mengalami penyusutan lahan sebesar 75 hektar setiap tahunnya. Peningkatan jumlah penduduk Kota Surabaya berbanding terbalik dengan ketersediaan lahan pertanian. Solusinya adalah menerapkan konsep baru urban farming. Hasil optimasi eksisting menghasilkan intensitas tanam sebesar $289 \%$ dengan pola tanam padi-palawija-palawija, sedangkan optimasi rencana menghasilkan intensitas tanam sebesar $\mathbf{2 4 0 \%}$ dengan pola tanam palawija-palawija (hidroponik tingkat atas), intensitas tanam sebesar $311 \%$ dengan pola tanam palawija-palawija-palawija (hidroponik tingkat bawah), dan budidaya ikan lele sistem bioflok. Kebutuhan air rencana sebesar 3,63x106 liter sedangkan ketersediaan tampungan air total sebesar 3,75x106 liter. Nilai Benefit Cost Ratio (BCR) eksisting dan rencana masing-masing sebesar 0,09 dan 1,43. Nilai Net Present Value (NPV) eksisting dan rencana masing-masing sebesar Rp115.719.410,06 dan Rp2.956.052.297,26. Nilai Payback Period (PP) eksisting dan rencana membutuhkan 12,39 tahun dan 1,7 tahun.
\end{abstract}

\section{Pendahuluan}

Surabaya merupakan kota terbesar kedua di Indonesia setelah Jakarta. Menurut Dinas Kependudukan dan Catatan Sipil Kota Surabaya jumlah penduduk Kota Surabaya pada tahun 2014 yaitu 2.848.583 jiwa. Pada tahun 2015 jumlah penduduk Kota Surabaya tercatat sebanyak 2.975.359 jiwa. Jumlah penduduk dari tahun 2014 sampai 2015 mengalami peningkatan sebesar 4,45\% [1]. Surabaya memiliki lahan pertanian sebesar 1.400 hektar. Lahan pertanian tersebut mengalami penyusutan lahan sebesar 75 hektar setiap tahunnya menurut Dinas Pertanian Kota Surabaya. Peningkatan jumlah penduduk Kota Surabaya berbanding terbalik dengan ketersediaan lahan pertanian [2].

Perbedaan antara peningkatan jumlah penduduk dan penurunan lahan menyebabkan harga sayur-sayuran di Surabaya semakin tinggi. Jumlah ketersediaan sayuran terbatas sedangkan permintaan semakin meningkat. Menurut data BPS Jatim pada Tahun 2016 Kota Surabaya mengalami inflasi sebesar $0,73 \%$. Komoditas sayur-sayuran penyumbang inflasi terbesar dari kelompok bahan makanan sebesar 2,36\% [1].

Untuk mengatasi ketidakseimbangan tersebut pemerintah Kota Surabaya membuat program urban farming. Menurut Bappeko Kota Surabaya program ini dituangkan dalam Rencana Pembangunan Jangka Menengah Daerah (RPJMD) tahun 2006-2010 dan dilanjutkan kembali pada tahun 20112015. Salah satu kegiatan urban farming ini terdapat di Kelurahan Made Kecamatan Sambikerep Surabaya. Luas lahan Urban Farming tersebut sebesar 211,85 hektar dan produksi tanaman mencapai 6.000 ton per tahun [1].

Pemerintah Kota Surabaya sejak tahun 2007 hingga tahun 2013 belum menentukan tolak ukur keberhasilan pelaksanaan urban farming. Pengembangan desain urban farming di seluruh wilayah Kota Surabaya termasuk Kelurahan Made berjalan lambat [1]. 
Oleh karena itu, diperlukan sebuah desain inovasi untuk mengembangkan urban farming di Kota Surabaya. Perencanaan Jaringan Irigasi Hidroponik Guna Ekstensifikasi Lahan pada Sawah Tadah Hujan di Kelurahan Made, Kecamatan Sambikerep, Kota Surabaya merupakan salah satu upaya untuk pengembangan urban farming tersebut.

\section{Metode}

\subsection{Konsep Urban Farming Made}

Konsep urban farming Made dapat dilihat pada Gambar 1 dengan penjelasan sebagai berikut ini:

a. Air hujan akan ditangkap oleh atap greenhouse. Air yang sudah dikumpulkan oleh atap akan dialirkan ke tampungan air (kolam budidaya ikan) melalui pipa dengan gaya gravitasi.

b. Air ini digunakan untuk membudidayakan ikan lele dengan metode bioflok. Air bekas dari ikan lele akan dialirkan ke kolam hidroponik sistem terapung melalui pipa dengan gaya gravitasi.

c. Air bekas budidaya ikan lele akan ditampung di kolam hidroponik sistem terapung yang dimanfaatkan sebagai aquaponik. Kandungan air bekas lele bermanfaat sebagai nutrisi untuk tanaman sawi.

d. Air bekas aquaponik dicampur dengan pupuk AB mix akan dipompa keatas dan akan digunakan sebagai hidroponik fertigasi tetes untuk tanaman cabai.

e. Air dengan pupuk AB mix tersebut akan dialirkan melalui pipa-pipa ke tanaman cabai. Air yang tidak diserap oleh tanaman cabai akan dikembalikan lagi ke kolam budidaya ikan.

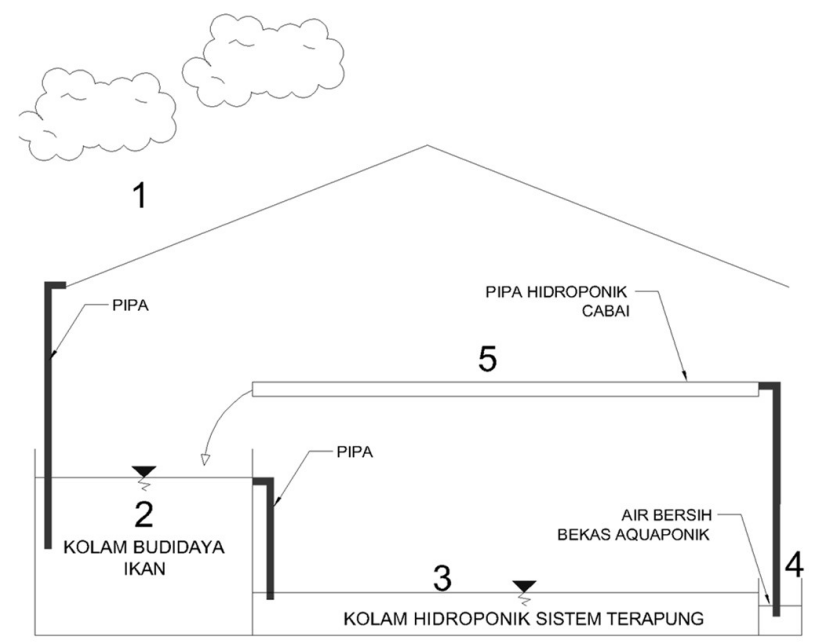

Gambar 1. Konsep Urban Farming Made

\subsection{Koefisien Pengaliran (C)}

Koefisien runoff sangat dipengaruhi oleh daerah kedap air seperti persamaan (1). Dimana Cp adalah koefisien runoff untuk daerah tidak kedap air, dan Im adalah rasio kedap air (luas kedap air dibagi dengan luas total) [3].

$$
\mathrm{C}=0,9 \mathrm{I}_{\mathrm{m}}+\left(1-\mathrm{I}_{\mathrm{m}}\right) \mathrm{C}_{\mathrm{p}}
$$

\subsection{Ketersediaan Penampungan Air Hujan (Inflow)}

Ketersediaan penampungan air hujan didapatkan dari air limpasan pada atap greenhouse seperti persamaan (2). C adalah koefisien limpasan, i adalah intensitas curah hujan, dan A adalah luas atap [4].

$$
\text { Runoff }=\mathrm{C} \text { i A }
$$

\subsection{Evapotranspirasi Peinmonteh}

Evapotranspirasi adalah gabungan dari dua peristiwa yakni evaporasi dan transpirasi yang terjadi secara bersamaan. Evapotranspirasi dipengaruhi beberapa faktor iklim seperti suhu udara, kelembaban, kecepatan angin, tekanan udara, sinar matahari. Beberapa metode untuk menghitung evapotranspirasi adalah rumus Blaney Criddle, Penmann dan TureLanghein-Wunt. Untuk daerah tropis besarnya evapotranspirasi yang terjadi dihitung menggunakan Metode Penman modifikasi FAO pada persamaan (3).

$$
\text { Eto }=c\left\{W \cdot R_{n}+(1-W) \cdot f(u) \cdot(\text { ea }-e d)\right\}
$$

Dimana c adalah faktor pergantian cuaca akibat siang dan malam, W adalah Faktor berat yang mempengaruhi penyinaran matahari pada evapotranspirasi potensial, $\mathrm{Rn}$ adalah radiasi penyinaran matahari dalam perbandingan penguapan atau radiasi matahari bersih (mm/hari), f (u) adalah Fungsi Pengaruh angin pada ETo, dan (ea-ed) adalah perbedaan tekanan uap air jenuh dengan tekanan uap air nyata (mbar) [5].

\subsection{Evapotranspirasi Greenhouse}

Stanghellini (1987) merevisi persamaan penman-Monteith (3) untuk mewakili kondisi di rumah kaca, di mana kecepatan udara biasanya rendah $(<1,0 \mathrm{~ms}-1)$. Model Stanghellini persamaan (4) - (7) meliputi perhitungan fluks panas radiasi matahari yang berasal dari karakteristik empiris dari gelombang pendek dan penyerapan radiasi gelombang panjang dalam kanopi Multi-lapisan. LAI adalah indeks area daun yang digunakan untuk memperhitungkan pertukaran energi dari beberapa lapisan daun pada tanaman rumah kaca (m2). Resistensi internal dan eksternal rc dan ra untuk kanopi yang digunakan adalah $70 \mathrm{detik} / \mathrm{m}$ dan $430 \mathrm{detik} / \mathrm{m}$. Kt adalah faktor konversi satuan waktu (3600 mm/jam), To adalah suhu daun $\left({ }^{\circ} \mathrm{C}\right), \mathrm{Cp}$ adalah spesifik udara $\left(\mathrm{MJ} / \mathrm{kg}{ }^{\circ} \mathrm{C}\right), \rho$ adalah kepadatan udara berarti $(\mathrm{kg} / \mathrm{m} 3), \quad \varepsilon$ adalah air untuk mengeringkan rasio berat molekul (-), $\lambda$ adalah panas laten dari vapourization $(\mathrm{MJ} / \mathrm{kg}), \sigma$ adalah konstan Stefan Boltzmann (MJ/m2K4hari), rR adalah resistensi radiatif 
(detik/m), P adalah tekanan atmosfer $(\mathrm{kPa})$, dan VPD adalah defisit tekanan uap $(\mathrm{kPa})$. [6]

$$
\begin{aligned}
& \mathrm{ET}_{\mathrm{o}}=2 \cdot L A I \frac{1}{\lambda} \frac{\Delta\left(\mathrm{R}_{\mathrm{n}}-\mathrm{G}\right)+\mathrm{K}_{\mathrm{t}} \frac{\text { VPD. } \rho \cdot \mathrm{C}_{\mathrm{p}}}{\mathrm{r}_{\mathrm{a}}}}{\Delta+\gamma\left(1+\frac{r_{c}}{r_{a}}\right)} \\
& \mathrm{R}_{\mathrm{n}}=0,07 \cdot R_{n s}-\frac{252 \cdot \rho \cdot C_{p} \cdot\left(T-T_{0}\right)}{r_{R}} \\
& \gamma=\frac{C_{p} \cdot P}{\varepsilon \lambda} \\
& \mathrm{r}_{\mathrm{R}}=\frac{\rho \cdot C_{p}}{4 \sigma(T+273,15)^{3}}
\end{aligned}
$$

\subsection{Evapotranspirasi Tanaman}

Evapotranspirasi tanaman (Etc, $\mathrm{mm} /$ hari) didapatkan dari koefisien tanaman $(\mathrm{Kc})$ dengan evapotransirasi tanaman acuan (Eto, $\mathrm{mm} /$ hari) pada persamaan (8). Nilai Kc cabai awal, vegetatif, pembungaan, pembuahan, dan pemasakan adalah 0,$4 ; 0,75 ; 1,1 ; 1 ;$ dan 0,9 [7]. Sedangkan nilai Kc sawi awal, tengah, dan akhir pertumbuhan adalah 0,$30 ; 1,20$; dan $0,60[8]$.

$$
\mathrm{ET}_{\mathrm{c}}=\mathrm{K}_{\mathrm{c}} \times \mathrm{ET}_{\mathrm{o}}
$$

\subsection{Intensitas Tanam}

Panen tanaman padi dan palawija dapat dilakukan lebih dari satu kali dalam setahun sehingga luas panen per tahun dapat dihitung dengan mengalikan antara intensitas pertanaman (Cropping Intensity) dengan luas baku sawah. Oleh karean itu Intensitas tanam bisa dihitung dengan persamaan (9). Dimana CI adalah intensitas tanam (kali/tahun), A adalah luas panen (ha), dan LS adalah luas baku sawa (ha) [9].

$$
\mathrm{CI}=\frac{\mathrm{A}}{\mathrm{LS}}
$$

\subsection{Kebutuhan Air pada Hidroponik (Outflow)}

Laju pemberian air yang tepat pada kolam hidroponik sistem terapung diperlukan untuk mempertahankan tinggi muka air atau mengkompensasi laju konsumsi air tanaman. Debit kebutuhan air dapat dihitung dengan persamaan (10). Dimana $Q$ adalah debit kebutuhan air $\left(\mathrm{m}^{3} /\right.$ hari), Etc adalah laju evapotranspirasi aktual ( $\mathrm{mm} /$ hari) pada Greenhouse, P adalah panjang kolam (m), dan L adalah lebar kolam (m) [10].

$$
\mathrm{Q}=\frac{\mathrm{ET}_{\mathrm{c}}}{1000} P L
$$

\subsection{Tampungan Air}

Tampungan air dihitung menggunakan metode Ripple atau kurva Massa. Metode ini menghitung besarnya kapasitas tampungan efektif untuk kebutuhan air yang konstan. Pada diagram Gambar 2 nilai Inflow (S) adalah debit kumulatif tampungan air dengan kemiringan kurva massa pada waktu tertentu. Outflow (D) adalah debit kebutuhan air dengan kemiringan kurva massa. Kapasitas penyimpanan (active storage) adalah nilai kumulatif maksimum antara garis singgung dari garis permintaan (D) ditarik pada titik tertinggi dan titik terendah dari kurva massa (S) memberikan tingkat penarikan dari tampungan air selama perode kritis [11].

\subsection{Analisa Ekonomi}

Analisa ekonomi yang digunakan pada penelitian ini adalah menggunakan metode Benefit Cost Ratio (BCR), metode Net Present Value (NPV), dan metode Payback Period (PP) [12].

Metode BCR ini memberikan penekanan terhadap nilai perbandingan antara aspek manfaat (benefit) yang akan diperoleh dengan aspek biaya dan kerugian yang akan ditanggung (cost) dengan adanya investasi tersebut. Metode ini sangat baik dilakukan dalam rangka mengevaluasi proyek-proyek pemerintah yang berdampak langsung pada masyarakat banyak (Public government project). Metode ini memiliki 2 kriteria. Jika BCR $>1$ artinya investasi layak (feasible) dan jika $\mathrm{BCR}<1$ artinya investasi tidak layak (unfeasible).

Metode NPV pada dasarnya memindahkan cash flow yang menyebar sepanjang umur investasi ke waktu awal investasi $(\mathrm{t}=0)$ atau kondisi present. Metode ini memiliki 2 kriteria. Jika NPV $\geq 0$ artinya investasi akan menguntungkan/layak (feasible) dan jika NPV $<0$ maka artinya investasi tidak menguntungkan/layak (unfeasible).

Analisis Payback Period pada dasarnya bertujuan untuk mengetahui seberapa lama (periode) investasi akan dapat dikembalikan saat terjadinya kondisi pulang pokok (break even-point). Lamanya periode pengembalian (k) saat kondisi cost-nya bersifat annual dapat dihitung dengan persamaan (11)

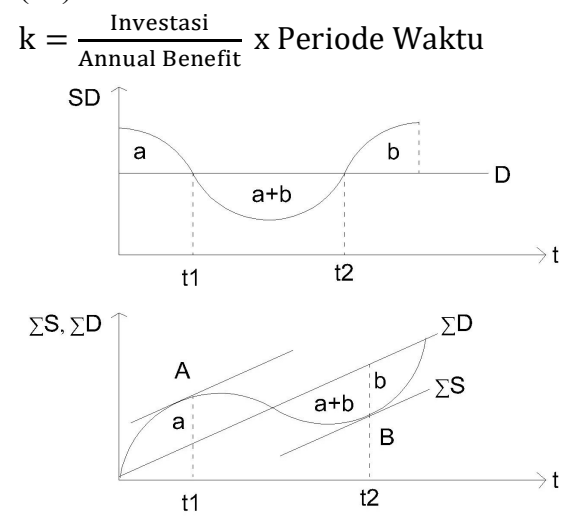

Gambar 2. Metode Kurva massa dan Analisis Kurva Massa [11] 


\section{Hasil dan Pembahasan}

\subsection{Koefisien Pengaliran (C)}

Koefisien pengaliran (C) didapat dari luasan atap Greenhouse sebesar 10.706,560 $\mathrm{m}^{2}$. Atap Greenhouse terbuat dari atap plastik yang bersifat kedap air. Rasio kedap air (Im) sebesar 1. Koefisien runoff untuk daerah tidak kedap air $(\mathrm{Cp})$ sebesar 0 karena semua daerah kedap air. Sehingga nilai koefiseien Pengaliran (C) sebesar 0,9.

\subsection{Ketersediaan Penampungan Air Hujan (Inflow)}

Ketersediaan penampungan air hujan didapatkan dari air limpasan (runoff) atap Greenhouse yang akan ditampung pada reservoir. Reservoir tersebut nantinya akan dimanfaatkan untuk kebutuhan air dari tanaman hidroponik dan budidaya ikan (aquaponik). Intensitas curah hujan (i) yang digunakan adalah rerata curah hujan atau sebesar 50\%. Volume penampungan air hujan dapat dilihat pada tabel 1 dan gambar 3. Pada Tabel 1 menunjukkan bahwa volume terbesar pada bulan Februari sebesar 3,723 juta liter. Sedangkan volume terkecil pada bulan Agustus sebesar 0,059 juta liter. Hal ini karena pada bulan Agustus adalah musim kemarau. Rata-rata volume dalam 1 tahun adalah sebesar 1,724 juta liter.

Tabel 1. Volume Penampungan Air Hujan

\begin{tabular}{lllllll}
\hline $\begin{array}{c}\mathrm{Bu} \\
\text { lan }\end{array}$ & $\begin{array}{l}\mathrm{I} \\
(\mathrm{mm})\end{array}$ & $\mathrm{A}\left(\mathrm{m}^{2}\right)$ & $\mathrm{C}$ & Runnoff & $\begin{array}{l}\text { Runnoff } \\
* *\end{array}$ & $\begin{array}{l}\text { Kumul } \\
\text { Runnoff }\end{array}$ \\
\hline Nov & 147 & 10706.59 & 0.900 & 1.417 & 1.417 & 1.417 \\
$\mathrm{Des}$ & 345 & 10706.59 & 0.900 & 3.327 & 3.327 & 4.744 \\
Jan & 325 & 10706.59 & 0.900 & 3.130 & 3.130 & 7.874 \\
Feb & 386 & 10706.59 & 0.900 & 3.723 & 3.723 & 11.596 \\
Mar & 371 & 10706.59 & 0.900 & 3.579 & 3.579 & 15.175 \\
Apr & 224 & 10706.59 & 0.900 & 2.158 & 2.158 & 17.333 \\
Mei & 159 & 10706.59 & 0.900 & 1.530 & 1.530 & 18.863 \\
Jun & 69 & 10706.59 & 0.900 & 0.663 & 0.663 & 19.526 \\
Jul & 32 & 10706.59 & 0.900 & 0.304 & 0.304 & 19.830 \\
Agu & 6 & 10706.59 & 0.900 & 0.059 & 0.059 & 19.889 \\
Sep & 17 & 10706.59 & 0.900 & 0.167 & 0.167 & 20.056 \\
Okt & 65 & 10706.59 & 0.900 & 0.628 & 0.628 & 20.684 \\
& & & & 1.724 & 1.724 & \\
& & & & & &
\end{tabular}

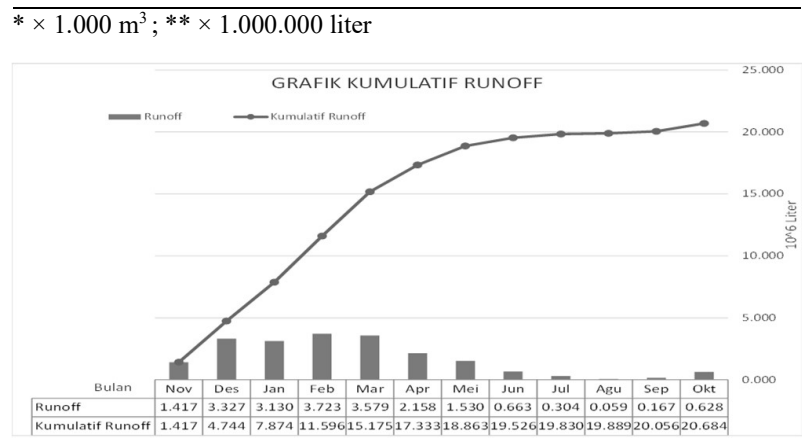

Gambar 3. Grafik Volume Penampungan Air Hujan.

3.3. Perbandingan Evapotranspirasi
Data klimatologi mengunakan dari Stasiun meteorologi Perak II Surabaya. Data klimatologi berupa data kelembaban, temperatur, lama penyinaran matahari, dan kecepatan angin. Jumlah data klimatologi adalah sebanyak 9 data, mulai dari tahun 2010 sampai dengan tahun 2018.

Menurut Stanghellini, greenhouse dapat mengurangi evapotranspirasi (ET) sebanyak 70\% dari sawah terbuka. Menurut Fernandes dalam Peter Tipis Ole Mpusia penggunaan greenhouse di daerah kering mengurangi kebutuhan tanaman air dengan mengurangi evapotranspiration [6].

Penutup plastik yang digunakan pada greenhouse berubah secara lokal keseimbangan radiasi dengan entrapping radiasi gelombang panjang dan menciptakan penghalang untuk kerugian kelembaban. Akibatnya ETo berkurang sebanyak $60 \%$ sampai $85 \%$ dibanding di luar rumah kaca. Hal ini berbanding lurus dengan penelitian ini dapat dilihat pada tabel 2 dan gambar 4 menunjukan bahwa nilai evapotranspirasi potensial harian (Eto) metode Stanghellini (indoor) lebih rendah daripada evapotranspirasi metode potensial harian (Eto) Penman Modifikasi (outdoor). Besaran penurunan evapotranspirasi dari 49,77\% sampai $76,09 \%$.

Tabel 2. Perbandingan Evapotranspirasi potensial (Eto)

\begin{tabular}{clcc}
\hline Bulan & $\begin{array}{c}\text { Eto } \\
\text { Indoor }\end{array}$ & $\begin{array}{c}\text { Eto } \\
\text { Outdoor }\end{array}$ & $\begin{array}{c}\text { Kum. } \\
\text { Outflow* }\end{array}$ \\
\hline Nov & 3.94 & 6.202 & $63.50 \%$ \\
Des & 3.08 & 5.123 & $60.10 \%$ \\
Jan & 2.936 & 5.476 & $53.60 \%$ \\
Feb & 2.897 & 5.822 & $49.80 \%$ \\
Mar & 3.122 & 5.934 & $52.60 \%$ \\
Apr & 3.122 & 5.322 & $58.70 \%$ \\
Mei & 3.527 & 5.123 & $68.90 \%$ \\
Jun & 3.697 & 5.067 & $73.00 \%$ \\
Jul & 4.028 & 5.294 & $76.10 \%$ \\
Agu & 4.586 & 6.088 & $75.30 \%$ \\
Sep & 4.824 & 6.796 & $71.00 \%$ \\
Okt & 5.213 & 7.121 & $73.20 \%$ \\
\hline
\end{tabular}

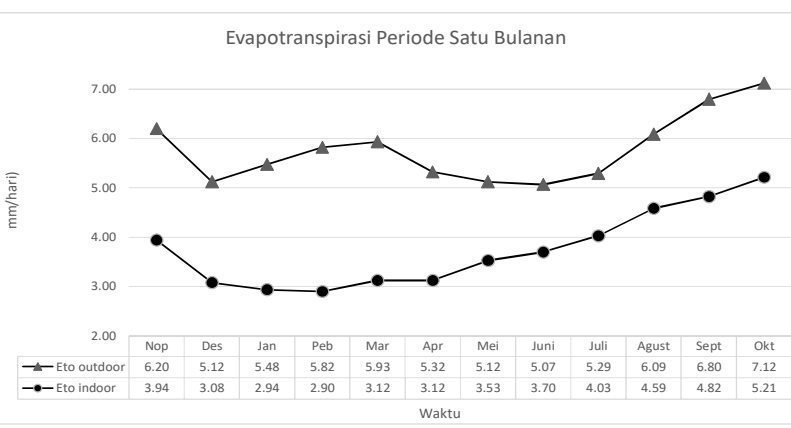

Gambar 4. Grafik Perbandingan Evapotanspirasi potensial (Eto) outdoor dengan indoor.

\subsection{Kebutuhan Air (Outflow)}

Kebutuhan air ini diperoleh dari kebutuhan air untuk tanaman yang berada di dalam greenhouse dan kebutuhan air 
untuk budidaya ikan. Desain irigasi terdiri dari 3 komponen yaitu hidroponik tingkat atas, tingkat bawah, dan tampungan air dapat dilihat pada gambar 5 dan 6.

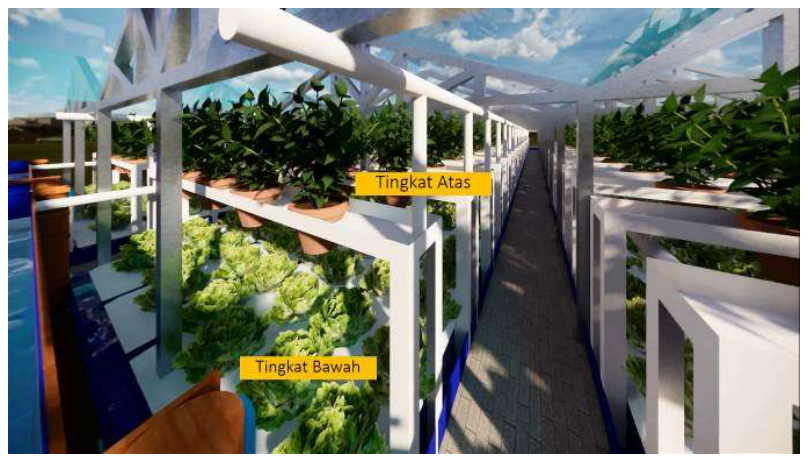

Gambar 5. Desain Hidroponik pada Urban Farming Made

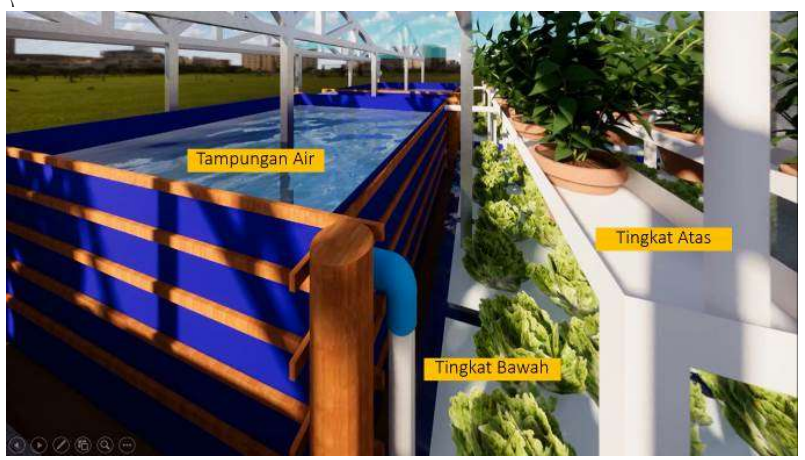

Gambar 6. Desain Tampungan Air pada Urban Farming Made

\subsection{Kebutuhan Air untuk Hidroponik Tingkat Atas}

Hidroponik tingkat atas akan ditanami tanaman cabai. Sistem irigasi hidroponik menggunakan sistem fertigasi hidroponik. Tanaman cabai ditanam di polybag yang diletakan sebuah angkringan. Irigasi tanaman cabai dialiri dengan metode irigasi tetes untuk memenuhi kebutuhan air dan nutrisi. Luas baku sawah (LS) yang ditanami cabai mencapai $100 \%$ dari luas total $(1,072 \mathrm{Ha})$. Dari hasil optimasi pola tanam tersebut didapatkan luas panen (A) sebesar 2,573 Ha. Sehingga intensitas tanam cabai adalah 2,4 kali dalam setahun atau sebesar $240 \%$. Pola tanam cabai dapat dilihat pada gambar 7. Kebutuhan air tanaman cabai dapat dilihat pada tabel 3 atau pada gambar 8 dan 9.

Pola Tanam Hidroponik Cabai

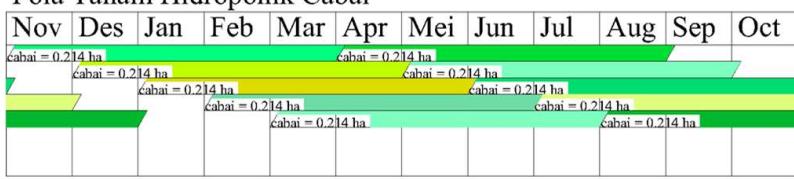

Gambar 7. Pola Tanam Hidroponik Cabai
Tabel 3. Kebutuhan Air untuk Hidroponik Cabai

\begin{tabular}{lcccrrr}
\hline Bulan & $\begin{array}{c}\text { Luas } \\
\text { (Ha) }\end{array}$ & $\begin{array}{c}\text { Q } \\
\text { (1/detik) }\end{array}$ & $\begin{array}{c}\text { Ouflow } \\
\text { cabai* }\end{array}$ & $\begin{array}{c}\text { Kum. } \\
\text { Outflow* }\end{array}$ & Inflow* & $\begin{array}{c}\text { Kum. } \\
\text { Inflow* }\end{array}$ \\
\hline Nov & 1.072 & 0.521 & 1.350 & 1.350 & 1.417 & 1.417 \\
Des & 1.072 & 0.474 & 1.268 & 2.618 & 3.327 & 4.744 \\
Jan & 1.072 & 0.504 & 1.350 & 3.968 & 3.130 & 7.874 \\
Feb & 1.072 & 0.505 & 1.222 & 5.190 & 3.723 & 11.596 \\
Mar & 1.072 & 0.469 & 1.255 & 6.445 & 3.579 & 15.175 \\
Apr & 1.072 & 0.510 & 1.322 & 7.767 & 2.158 & 17.333 \\
Mei & 1.072 & 0.592 & 1.585 & 9.352 & 1.530 & 18.863 \\
Jun & 1.072 & 0.602 & 1.559 & 10.912 & 0.663 & 19.526 \\
Jul & 1.072 & 0.620 & 1.662 & 12.573 & 0.304 & 19.830 \\
Agu & 1.072 & 0.624 & 1.672 & 14.246 & 0.059 & 19.889 \\
Sep & 1.072 & 0.607 & 1.573 & 15.819 & 0.167 & 20.056 \\
Okt & 1.072 & 0.643 & 1.723 & 17.542 & 0.628 & 20.684 \\
\hline$* \times 1.000 .000$ liter & & & & &
\end{tabular}

3.6. Kebutuhan Air untuk Hidroponik Tingkat Bawah Hidroponik tingkat bawah akan ditanami tanaman sawi. Dalam penelitian yang dilakukan Suryo Adi Wibowo tentang pengaruh pemberian naungan dengan intensitas cahaya terhadap pertumbuhan sawi [13]. Dimana penelitian itu membandingkan 3 perlakuan naungan yaitu tanpa naungan $0 \%$, dengan naungan $50 \%$, dan dengan naungan $75 \%$. Hasil dari penelitian menyatakan bahwa sawi yang di naungan dengan intensitas cahaya 50\% memberikan pertumbuhan dan hasil yang terbaik dibandingkan dengan naungan dengan intensitas cahaya $25 \%$ maupun tanpa naungan. Pada hidroponik tingkat atas yang ditanami dengan cabai memiliki jarak $60 \mathrm{~cm}$ x 60 $\mathrm{cm}$ untuk setiap tanaman. Hal ini mengakibatkan intensitas cahaya untuk tanaman sawi berkurang. Oleh karena itu, tanaman sawi dipilih untuk hidroponik tingkat bawah.

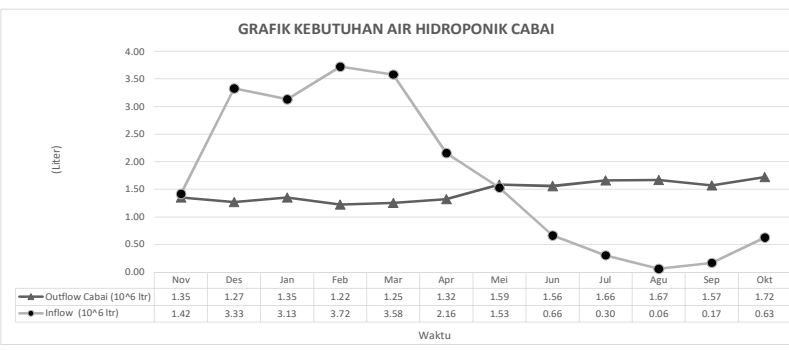

Gambar 8. Grafik Kebutuhan Air untuk Hidroponik Cabai

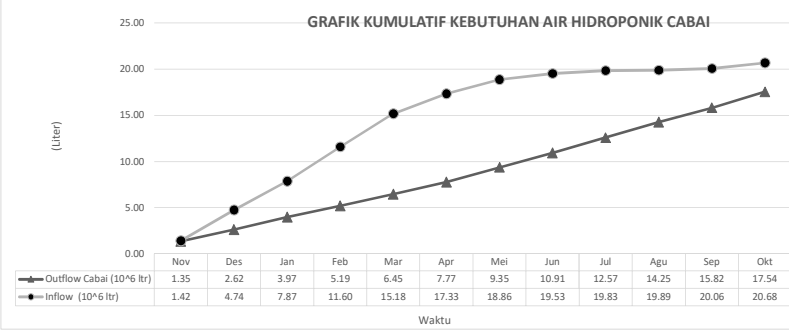

Gambar 9. Grafik Kebutuhan Air untuk Hidroponik Cabai

Sistem hidroponik tanaman sawi berupa teknologi hidroponik sistem terapung (THST). Teknologi ini dipilih 
karena lebih mudah daripada sistem fertigasi hidroponik. Teknologi ini hanya diletakkan di atas kolam tampungan dengan ketinggian $40 \mathrm{~cm}$ tanpa menggunakan pompa untuk mengaliri air. Luas baku sawah (LS) yang digunakan untuk $80 \%(0,858 \mathrm{Ha})$ dari luas total $(1,072 \mathrm{Ha})$ atau $89 \%$ dari luas tampungan air $(0,965 \mathrm{Ha})$ dan $11 \%$ dari luas tampungan air digunakan sebagai ruang kosong untuk sirkulasi cahaya dan udara pada pertumbuhan budidaya ikan. Dari hasil optimasi didapatkan luas panen (A) sebesar 2,668 Ha. Sehingga menghasilkan intensitas tanam sebesar 3,11 kali dalam setahun atau sebesar $311 \%$. Pola tanam sawi dapat dilihat pada gambar 10.

Pola Tanam Hidroponik Sawi

\begin{tabular}{|l|l|l|l|l|l|l|l|l|l|l|l}
\hline Nov & Des & Jan & Feb & Mar & Apr & Mei & Jun & Jul & Aug & Sep & Oct \\
\hline
\end{tabular}

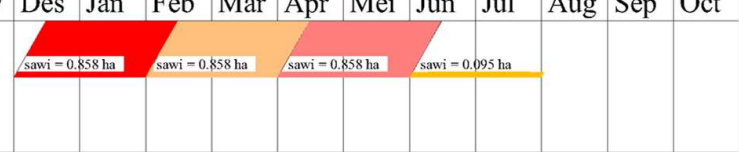

Gambar 10. Pola Tanam Hidroponik Sawi

Kebutuhan air untuk hidroponik tingkat bawah (sawi) didapatkan dari sisa air kebutuhan tanaman cabai. Sehingga inflow sawi pada tabel $\mathbf{4}$ adalah hasil pengurangan dari inflow air hujan dikurangi dengan outflow tanaman cabai. Hal ini untuk mengoptimalkan ketersediaan air hujan (inflow) secara maksimal. Kebutuhan air tanaman sawi dapat dilihat pada tabel 4 atau pada gambar 11 dan 12 .

Tabel 4. Kebutuhan Air untuk Hidroponik Sawi

\begin{tabular}{lllllll}
\hline $\begin{array}{l}\text { Bulan Luas } \\
\text { (Ha) }\end{array}$ & $\begin{array}{l}\text { Q } \\
(1 / \text { detik })\end{array}$ & $\begin{array}{l}\text { Ouflow } \\
\text { sawi* }\end{array}$ & $\begin{array}{l}\text { Kum. } \\
\text { Outflow } \\
\text { sawi* }\end{array}$ & $\begin{array}{l}\text { Inflow } \\
\text { sawi } *\end{array}$ & $\begin{array}{l}\text { Kum. } \\
\text { Inflow } \\
\text { sawi* }\end{array}$ \\
\hline Nov & 0.000 & 0.000 & 0.000 & 0.000 & 0.067 & 0.067 \\
Des & 0.858 & 0.272 & 0.728 & 0.728 & 2.059 & 2.125 \\
Jan & 0.858 & 0.108 & 0.289 & 1.017 & 1.780 & 3.906 \\
Feb & 0.858 & 0.256 & 0.618 & 1.635 & 2.501 & 6.406 \\
Mar & 0.858 & 0.115 & 0.307 & 1.943 & 2.324 & 8.730 \\
Apr & 0.858 & 0.275 & 0.714 & 2.657 & 0.836 & 9.566 \\
Mei & 0.858 & 0.13 & 0.347 & 3.004 & -0.055 & 9.510 \\
Jun & 0.095 & 0.036 & 0.093 & 3.098 & -0.896 & 8.614 \\
Jul & 0.095 & 0.016 & 0.044 & 3.141 & -1.358 & 7.256 \\
Agu & 0.000 & 0.000 & 0.000 & 3.141 & -1.614 & 5.643 \\
Sep & 0.000 & 0.000 & 0.000 & 3.141 & -1.406 & 4.237 \\
Okt & 0.000 & 0.000 & 0.000 & 3.141 & -1.095 & 3.141 \\
\hline
\end{tabular}

\subsection{Tampungan Air.}

Tampungan air ini memiliki 2 fungsi. Yang pertama menjadi tempat penyimpanan air untuk kebutuhan air irigasi (hidroponik tingkat atas dan bawah). Yang kedua sebagai budidaya ikan tawar. Pemanfaatan ini bisa menambahkan keuntungan dari pembudidayaan ikan pada sistem ini. Selain itu kotoran yang dihasilkan oleh ikan bisa digunakan sebagai pupuk dan nutrisi untuk tanaman sawi. Hal ini dapat menghemat pengeluaran untuk membeli pupuk dan nutrisi.
Luasan tampungan air terdiri dari $90 \%(0,965 \mathrm{Ha})$ dari luas total $(1,072 \mathrm{Ha})$ dan $10 \%$ dari luas total digunakan sebagai jalan akses untuk mempermudahkan operasi dan pemeliharaan irigasi. Tampungan air memiliki 2 macam kolam yaitu kolam budidaya ikan seluas $10 \%(0,107 \mathrm{Ha})$ dari luas total dan kolam hidroponik sistem terapung seluas $80 \%(0,858 \mathrm{Ha})$ dapat dilihat pada gambar 13.

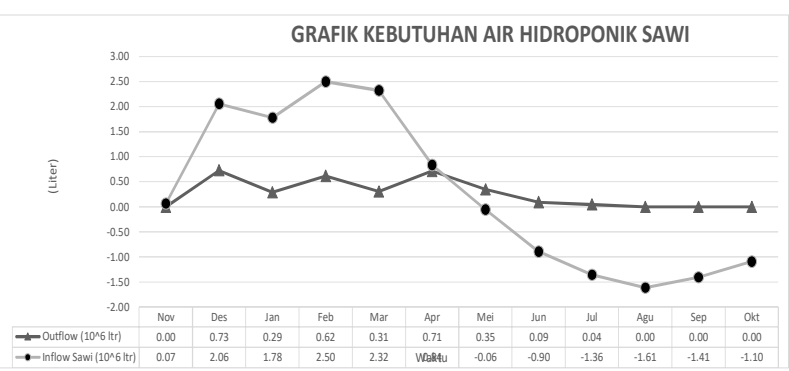

Gambar 11. Grafik Kebutuhan Air untuk Hidroponik Sawu

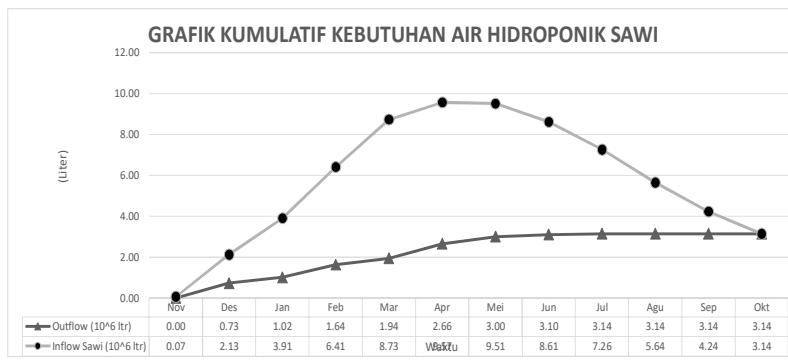

Gambar 12. Grafik Kebutuhan Air untuk Hidroponik Sawi

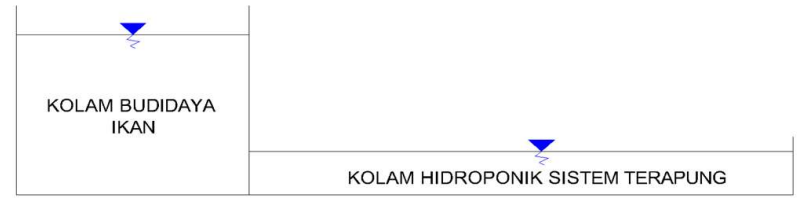

Gambar 13. Sketsa Kolam pada Urban Farming Made.

3.8. Kebutuhan Tampungan Air untuk Kebutuhan Tanaman Cabai dan Sawi.

Kebutuhan tampungan air didapatkan dari kebutuhan air total dari tanaman cabai dan sawi dapat dilihat pada tabel 5 atau gambar 14 dan 15. Tampungan minimal sebesar -1,613 juta liter, tampungan maksimal sebesar 2,017 juta liter, sedangkan kebutuhan tampungan air sebesar 3,630 juta liter.

3.9. Kebutuhan Tampungan Air untuk Kolam Budidaya Ikan

Kolam budidaya ikan berbentuk persegi panjang yang terbuat dari kerangkan besi diameter $6 \mathrm{~cm}$ dengan dilapisi terpal. Desain Perencanaan kolam untuk budidaya ikan memiliki tinggi 1,3 m dengan kedalaman air 1,1 m. Luas kolam sebesar $1,720 \mathrm{~m}^{2}$. Sehingga volume kolam budidaya ikan sebesar 1,180 juta liter. 
Tabel 5. Kebutuhan Air untuk Total

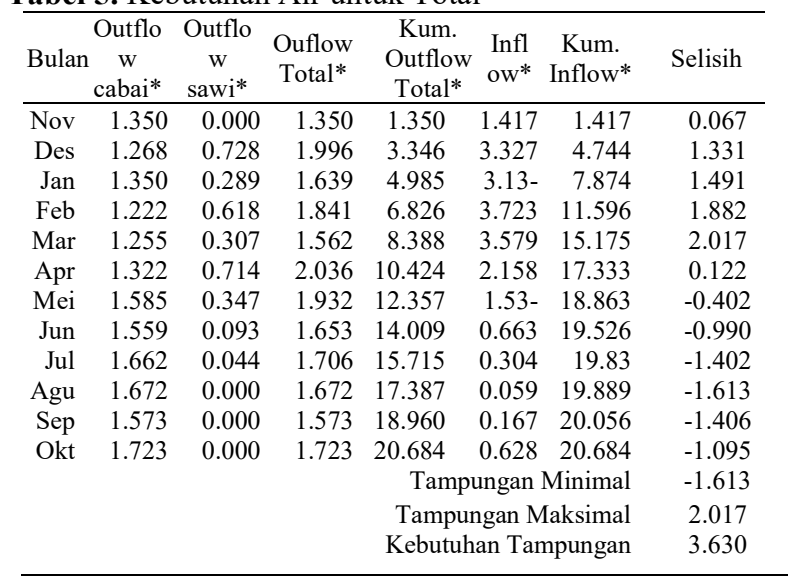

$* \overline{\times 1.000 .000 \text { liter }}$

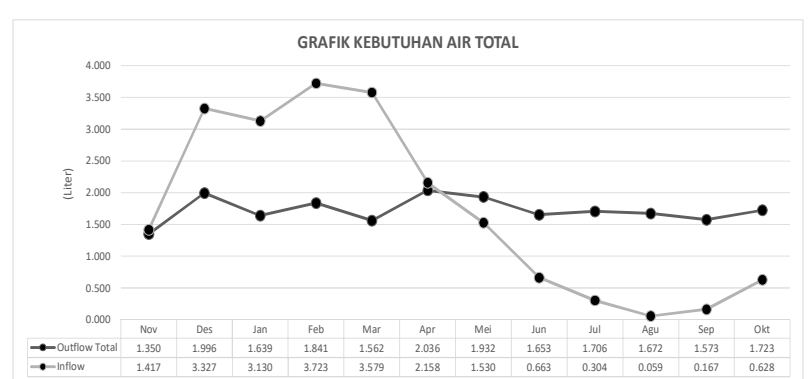

Gambar 14. Grafik Kebutuhan Air Total

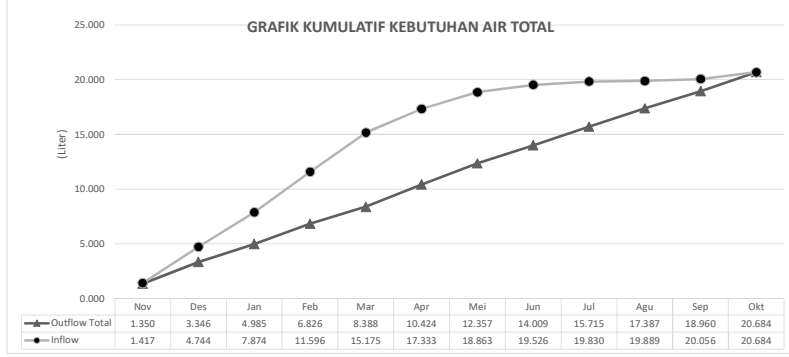

Gambar 15. Grafik Kebutuhan Air Total

3.10. Kebutuhan Tampungan Air untuk Kolam Budidaya Sawi Teknologi Hidroponik Sistem Terapung (THST)

Kolam untuk budidaya sawi dengan menggunkan teknologi hidroponik sistem terapung (TSHT) berbentuk persegi panjang yang akan di tutup styrofoam sebagai media apung tanaman sawi. Luas kolam sebesar $8.576 \mathrm{~m} 2$. Ketinggian kolam sebesar $40 \mathrm{~cm}$ dengan kedalaman air $30 \mathrm{~cm}$. Sehingga volume kolam hidroponik sistem terapung sebesar 2,570 juta liter.

\subsection{Water Balance}

Water balance adalah keseimbangan penggunaan air antara kebutuhan air (outflow) dengan ketersedian air (inflow) Kebutuhan air total sebesar 3,630 juta liter. Ketersediaan air dari kolam budidaya ikan sebesar 1,180 juta liter ditambah dari kolam hidroponik sistem terapung sebesar 2,570 juta liter menghasilkan ketersediaan air total sebesar 3,750 juta liter. Sehingga surplus water balance sebesar $+0,120$ juta liter.

\subsection{Blok dan Pedoman Awal Taman}

Pembagian blok bertujuan untuk memudahkan pola operasi dan pemeliharan jaringan irigasi. Pedoman awal tanam bertujuan untuk memudahkan dalam penjadwalan awal tanam yang disesuikan dengan hasil optimasi. Pebagian blok dan pedoman awal tanam dapat dilihat pada tabel 6 dan gambar 16.

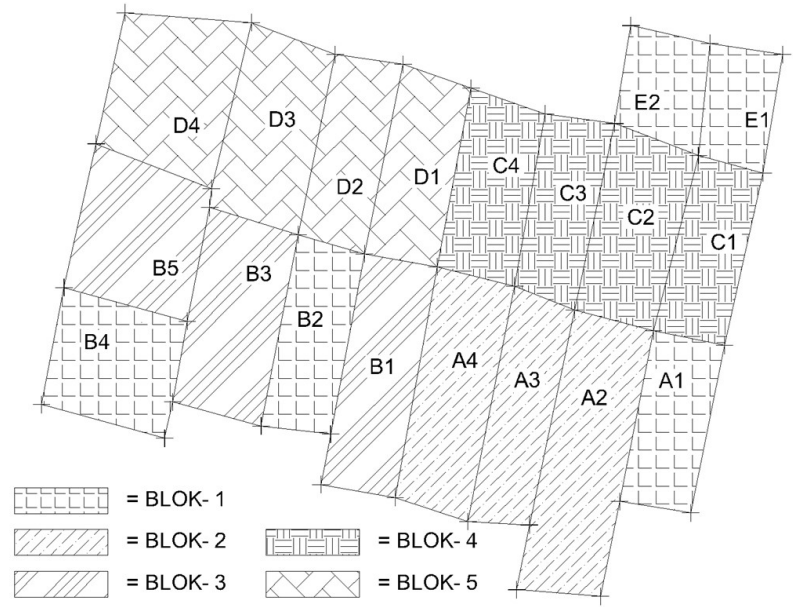

Gambar 16. Blok Tersier pada Urban Farming Made.

\subsection{Analisa Ekonomi}

Analisa ekonomi bertujuan untuk mengetahui apakah proyek ini bisa atau tidak dikerjakan. Analisa berupa benefit cost rasio (BCR), net present value (NPV), dan payback period (PP). Pendapatan (benefit) urban farming Made didapatkan dari penjualan cabai hidroponik, sawi hidroponik, dan ikan lele. Hasil produksi tanaman hidroponik lebih besar dari tanaman konvensional. Harga penjualan tanaman hidroponik lebih mahal dibandingkan dengan tanaman model konvesnional. Hal inilah yang menghasilkan banyak pendapatan dengan sistem hidroponik.

Hasil produksi cabai dengan sistem hidroponik dapat menghasilkan 35 ton/ha. Hasil produksi sawi dengan sistem hidropinik dapat menghasilkan 50 ton/ha menurut penelitian dari Simbolon (2011) [14]. Hasil produksi ikan lele dengan sistem bioflok lebih besar daripada sistem konvensional. Padat tebar dengan menggunakan sistem bioflok sebesar 1000 ekor/m3 dengan hasil panen sebesar $93 \mathrm{~kg} / \mathrm{m} 3$ [15]. Dalam proyek ini ada 2 model kolam ikan yang bisa 
dimanfaatkan. Kolam budidaya ikan dengan tinggi 1,3 meter yang menghasilkan 4 siklus pertahun dan kolam hidroponik sawi terapung hanya 2 siklus per tahun. Hal ini dikarenakan kolam hidroponik sawi dimanfaatkan untuk menanam sawi selama 6 bulan dengan sistem hidroponik terapung yang mana kolam akan ditutup dengan styrofoam. Total pendapatan urban farming sebesar Rp16.625.534.956,38 dapat dilihat pada tabel 7 .

Tabel 6. Blok dan Pedoman Awal Tanam

\begin{tabular}{|c|c|c|c|c|c|}
\hline No & Blok & Tanaman & $\begin{array}{c}\text { Awal } \\
\text { Tanam }\end{array}$ & Petak Tersier & Luas \\
\hline 1 & BLOK-1 & $\begin{array}{l}\text { Cabai I } \\
\text { Cabai II } \\
\text { Cabai III } \\
\text { Sawi I } \\
\text { Sawi II } \\
\text { Sawi III } \\
\text { Sawi IV }\end{array}$ & $\begin{array}{c}\text { Nov } \\
\text { Apr } \\
\text { Sep } \\
\text { Des } \\
\text { Feb } \\
\text { April } \\
\text { Jun }\end{array}$ & $\begin{array}{c}\mathrm{A} 1, \mathrm{~B} 2, \mathrm{~B} 4, \\
\mathrm{E} 1, \mathrm{E} 2\end{array}$ & 0,218 \\
\hline 2 & BLOK-2 & $\begin{array}{l}\text { Cabai I } \\
\text { Cabai II } \\
\text { Cabai III } \\
\text { Sawi I } \\
\text { Sawi II } \\
\text { Sawi III }\end{array}$ & $\begin{array}{l}\text { Des } \\
\text { Mei } \\
\text { Okt } \\
\text { Des } \\
\text { Feb } \\
\text { April }\end{array}$ & $\mathrm{A} 2, \mathrm{~A} 3, \mathrm{~A} 4$ & 0,211 \\
\hline 3 & BLOK-3 & $\begin{array}{l}\text { Cabai I } \\
\text { Cabai II } \\
\text { Sawi I } \\
\text { Sawi II } \\
\text { Sawi III }\end{array}$ & $\begin{array}{l}\text { Jan } \\
\text { Jun } \\
\text { Des } \\
\text { Feb } \\
\text { April }\end{array}$ & B1, B3, B5 & $\begin{array}{l}0,201 \\
0,161\end{array}$ \\
\hline 4 & BLOK-4 & $\begin{array}{l}\text { Cabai I } \\
\text { Cabai II } \\
\text { Sawi I } \\
\text { Sawi II } \\
\text { Sawi III } \\
\text { Sawi IV }\end{array}$ & $\begin{array}{l}\text { Feb } \\
\text { Jul } \\
\text { Des } \\
\text { Feb } \\
\text { April } \\
\text { Jun }\end{array}$ & $\begin{array}{c}\mathrm{C} 1, \mathrm{C} 2, \mathrm{C} 3, \\
\mathrm{C} 4\end{array}$ & $\begin{array}{l}0,206 \\
0,165\end{array}$ \\
\hline 5 & BLOK-5 & $\begin{array}{l}\text { Cabai I } \\
\text { Cabai II } \\
\text { Sawi I } \\
\text { Sawi II } \\
\text { Sawi III }\end{array}$ & $\begin{array}{l}\text { Mar } \\
\text { Agu } \\
\text { Des } \\
\text { Feb } \\
\text { April }\end{array}$ & $\begin{array}{l}\text { D1, D2, } \\
\text { D3, D4 }\end{array}$ & $\begin{array}{l}0,236 \\
0,189\end{array}$ \\
\hline
\end{tabular}

Tabel 7. Pendapatan Urban Farming Made

\begin{tabular}{|c|c|c|c|c|c|}
\hline $\begin{array}{l}\text { Urai } \\
\text { an }\end{array}$ & $\begin{array}{c}\text { Luas } \\
\text { Tanam } \\
(\mathrm{Ha}) \\
\end{array}$ & $\begin{array}{c}\text { Hasil } \\
\text { Produksi } \\
(\text { Ton } / \mathrm{Ha}) \\
\end{array}$ & $\begin{array}{c}\text { Hasil } \\
\text { Produksi } \\
\text { (Ton) } \\
\end{array}$ & $\begin{array}{c}\text { Harga per } \\
\text { Kg. } \\
(\mathrm{Rp})\end{array}$ & $\begin{array}{l}\text { Total } \\
\text { (Rp) }\end{array}$ \\
\hline Cabai & 2.573 & 35.00 & $90,048.00$ & $30,000.00$ & $2,701,440,000.00$ \\
\hline $\begin{array}{c}\text { Sawi } \\
\text { Lele }\end{array}$ & 2.668 & 50.00 & $133,377.87$ & $16,000.00$ & $2,134,045,996.38$ \\
\hline * & 1.072 & 331.45 & $355,316.54$ & $15,000.00$ & $5,329,748,160.00$ \\
\hline$* *$ & 1.072 & 401.76 & $\begin{array}{r}430,686.72 \\
\text { Total }\end{array}$ & $15,000.00$ & $\begin{array}{r}6,460,300,800.00 \\
16,625,534,956.38 \\
\end{array}$ \\
\hline
\end{tabular}

Biaya (cost) urban farming Made didapatkan dari biaya tetap untuk tenaga kerja pada tabel $\mathbf{8}$, biaya tetap bangunan pada tabel 9, dan biaya variabel pada tabel 10. Biaya tetap untuk tenaga kerja dalam setahun sebesar Rp1.168.694.400,00. Biaya tetap untuk bangunan meliputi pembuatan greenhouse, peralatan, saluran irigasi, sewa lahan, dan biaya listrik sebesar Rp375.010.396,27. Harga dari pembuatan greenhouse, peralatan, saluran irigasi, dan fasilitas dihitung dengan mempertimbangkan nilai penyusutan. Biaya variabel pertahun sebesar Rp5.291.036.533,29. Jadi total biaya operasional sebesar Rp6.834.741.329,56. sehingga keuntungannya sebesar Rp9.790.793.626,82.

Analisa ekonomi menggunakan metode benefit cost ratio (BCR) sebesar 1,43. Nilai BCR proyek ini memenuhi syarat karena melebihi dari $1(>1)$. Analisa dengan metode net present value (NPV) Rp2.956.052.297,26. Nilai NPV proyek ini memenuhi syarat karena melenihi dari $0(>0)$. Analisa metode payback period (PP) membutuhkan 1,7 tahun untuk kembali modal. Dari analisa ekonomi dengan berbagai metode diketahui bahwa proyek ini layak untuk dikerjakan.

Tabel 8. Biaya Tetap Tenaga Kerja

\begin{tabular}{cccccc}
\hline Uraian & $\begin{array}{c}\text { Volu } \\
\text { me } \\
\text { (org) }\end{array}$ & $\begin{array}{l}\text { Bula } \\
\mathrm{n}\end{array}$ & $\begin{array}{l}\text { Luas } \\
(\mathrm{Ha})\end{array}$ & $\begin{array}{c}\text { Harga satuan } \\
(\mathrm{Rp})\end{array}$ & $\begin{array}{c}\text { Total } \\
(\mathrm{Rp})\end{array}$ \\
\hline Persemaian & 8.00 & 12.00 & 1.072 & $125,000.00$ & $321,600,000.00$ \\
Panen & 8.00 & 12.00 & 1.072 & $125,000.00$ & $241,200,000.00$ \\
Pasca & 8.00 & 12.00 & 1.072 & $125,000.00$ & $321,600,000.00$ \\
Panen & & & & & \\
Pengawas & 8.00 & 12.00 & 1.072 & $4,200,000.00$ & $162,086,400.00$ \\
Manajer & 8.00 & 12.00 & 1.072 & $5,000,000.00$ & $64,320,000.00$ \\
Asisten & 8.00 & 12.00 & 1.072 & $4,500,000.00$ & $57,888,000.00$ \\
Manajer & & & & & \\
\hline \multicolumn{2}{c}{} & & & Total & \multicolumn{2}{c}{$1,168,694,400.00$}
\end{tabular}

Tabel 9. Biaya Tetap Bangunan

\begin{tabular}{lrrr}
\hline \multicolumn{1}{c}{ Uraian } & Volume & \multicolumn{1}{c}{$\begin{array}{c}\text { Harga satuan } \\
(\mathrm{Rp})\end{array}$} & \multicolumn{1}{c}{$\begin{array}{c}\text { Total } \\
(\mathrm{Rp})\end{array}$} \\
\hline Sewa Lahan & $10,720.00$ & 500.00 & $5,360,000.00$ \\
Biaya Listrik & 1.00 & $1,800,000.00$ & $1,800,000.00$ \\
Greenhouse & $9,561.03$ & $9,750.00$ & $93,220,050.30$ \\
Sarana Irigasi & 1.00 & $4,200,000.00$ & $123,308,603.73$ \\
Kolam & 1.00 & $149,727,397.20$ & $149,727,397.20$ \\
Fasilitas & 1.00 & $1,594,345.04$ & $1,594,345.04$ \\
Greenhouse & & & \\
\hline \multicolumn{2}{c}{ Total } & & $375,010,396.27$
\end{tabular}

Tabel 10. Biaya Variabel

\begin{tabular}{lrrrrr}
\hline \multicolumn{1}{c}{ Bulan } & Satuan & \multicolumn{1}{c}{ Volume } & $\begin{array}{l}\text { Lu } \\
\text { as }\end{array}$ & $\begin{array}{c}\text { Harga } \\
\text { Satuan }\end{array}$ & Total (Rp) \\
\hline $\begin{array}{l}\text { Tanaman Cabai } \\
\text { Bibit }\end{array}$ & Pcs & $7,172.57$ & 2.57 & 65.00 & $1,199,484.00$ \\
$\begin{array}{l}\text { Media Tanam } \\
\text { Tanaman Sawi }\end{array}$ & $\mathrm{Kg}$ & $358,628.73$ & 2.57 & $2,000.00$ & $1,845,360,000.00$ \\
Bibit & $\mathrm{Kg}$ & 0.60 & 2.67 & $120,000.00$ & $192,064.14$ \\
Rockwool & $\mathrm{Pcs}$ & $88,889.00$ & 2.67 & 100.00 & $23,711,651.82$ \\
Ikan Lele & & & & & \\
Bibit & $\mathrm{Ek}$ & $3,500,000.00$ & 1.07 & 125.00 & $469,000,000.00$ \\
Pakan & $\mathrm{Kg}$ & $280,000.00$ & 1.07 & $8,200.00$ & $2,461,312,000.00$ \\
Probiotik & $\mathrm{Ltr}$ & 933.33 & 1.07 & $25,000.00$ & $25,013,333.33$ \\
Molase & $\mathrm{Ltr}$ & $23,333.33$ & 1.07 & $6,000.00$ & $150,080,000.00$ \\
Tepung & $\mathrm{Kg}$ & $46,666.67$ & 1.07 & $6,000.00$ & $300,160,000.00$ \\
Premix & $\mathrm{Kg}$ & 46.67 & 1.07 & $250,000.00$ & $12,506,666.67$ \\
Desinfektan & $\mathrm{Btl}$ & 233.33 & 1.07 & $10,000.00$ & $2,501,333.33$ \\
\hline & & & Total & & $5,291,036,533.29$
\end{tabular}

\section{Simpulan}


Berdasarkan hasil pembahasan maka dapat disimpulkan sebagai berikut:

1. Intensitas tanam sebesar $240 \%$ dengan pola tanam Palawija-Palawija untuk hidroponik tingkat atas dan intensitas tanam sebesar $311 \%$ dengan pola tanam Palawija-Palawija untuk hidroponik tingkat bawah.

2. Kebutuhan air rencana sebesar 3,630 juta liter sedangkan ketersediaan tampungan air total sebesar 3,750 juta liter (kolam ikan sebesar 1,180 juta liter dan kolam hidroponik herpung sebesar 2,570 juta liter). Sehingga mengahsilkan defisit air sebesar $+0,120$ juta liter.

3. Nilai benefit cost ratio (BCR) 1,43. Nilai net present value (NPV) Rp2.956.052.297,26. dan nilai payback period (PP) membutuhkan 1,7 tahun.

\section{Daftar Pustaka}

[1] Dewi, Renny Ratna dan Eko Budi Santoso. Arahan Peningkatan Pengelolaan Program Urban Farming di Kelurahan Made Kecamatan Sambikerep Surabaya. Jurnal Perencanaan Wilayah dan Kota Volume 5 No 2. Surabaya: Institut Teknologi Sepuluh Nopember (2016) Hal C203 - C208

[2] Putra, Yudha Manggala. (2016. 18 Maret). Lahan Pertanian di Surabaya Menyusut [online]. Pada https:/www.republika.co.id/

[3] SNI 2415-2016 Tata Cara Perhitungan Debit Banjir Rencana

[4] Lade, Omolara dan David Olok. Assessment of Rainwater Harvesting Potential in Ibadan. Nigeria. West Midlands: School of Technology. University of Wolverhampton. Environ. Eng. Res. 2013 June.18(2): 91-94.

[5] Doorenbos J, WO Pruitt. Guidelinis for Predicting Crop Water Requirement Book 24. FAO. Rome (1977) 144 p.

[6] Mpusia, Peter Tipis Ole. Comparison of Water Consumption between Greenhouse and Outdoor Cultivation. Thesis. Enschede: International Institute For Geo-Information Science And Earth Observation (2006) hal 15-19.

[7] Supriadi, Devie Rienzani, Anas D. Susila, dan Eko Sulistyono. Penetapan Kebutuhan Air Tanaman Cabai Merah (Capsicum annuum L.) dan Cabai Rawit (Capsicum frutescens L.). J. Hort. Indonesia, April 2018, 9(1): 38-46

[8] Sari, Dinda Puspa. Kajian kinerja irigasi tetes pada tanah andosol dengan budidaya tanaman caisim (Braassica Juncea L.). Medan: Universitas Sumatera
Utara. J. Rekayasa Pangan dan Pert., Vol.2 No.3 Tahun (2016).

[9] Maulana, Mohamad. Peranan Luas Lahan, Intensitas Pertanaman Dan Produktivitas Sebagai Sumber Pertumbuhan Padi Sawah Di Indonesia 1980 - 2001. Bogor: Pusat Penelitian dan Pengembangan Sosial Ekonomi Pertanian. Jurnal Agro Ekonomi, Volume 22 No.1, Mei 2004: 74 - 95

[10] Muharomah, Riani. Analisis Laju Konsumsi Air Tanaman Selada Pada Teknologi Hidroponik Sistem Terapung Dalam Rumah Tanaman. Thesis. Bogor: Institut Pertanian Bogor Tahun (2017) hal 7.

[11] Ulfa, Azura. Perhitungan Kinerja Waduk Dan Evaluasi Kapasitas Waduk Ngancar Batuwarno, Wonogiri, Jawa Tengah. Yogyakarta: UGM. Jurnal Bumi Indonesia Volume 5. Nomer 4 Tahun (2016).

[12] Giatman, M. Ekonomi Teknik. Jakarta: Rajawali Pres, (2011). Hal 67-90.

[13] Wibowo, Suryo Adhi. Pengaruh Pemberian Naungan Dengan Intensitas Cahaya Yang Berbeda Terhadap Pertumbuhan Dan Hasil Berbagai Jenis Tanaman Sawi (Brassica Juncea L) Yogyakarta: Universitas Sarjanawiyata Tamansiswa. Jurnal Ilmih Agroust Vol 2. No. 1 Tahun (2018).

[14] Moerhasrianto, PradytoRespon Pertumbuhan Tiga Macam Sayuran Pada berbagai konsentrasi nutrisi larutan hidroponik, Jember: Universitas Jember Skripsi Tahun (2011)

[15] Direktorat Produksi dan Usaha Budidaya KPP RI. Budidaya Ikan Lele Sistem Biofok. Buku Saku. Jakarta tahun (2017) 
Halaman ini sengaja dikosongkan 